DOI: $10.15503 /$ jecs20141-261-284

\title{
THE ECONOMIC GROWTH OF SMALL STATES AND SMALL ECONOMIES IN REGIONAL ECONOMIC ORGANIZATIONS AND INTEGRATIONS: SIMILARITIES AND DIFFERENCES
}

\author{
PETAR KUREČIĆ \\ Business School Zagreb \\ E-mail adress: petar.kurecic@vpsz.hr \\ ĐANA LUŠA \\ Faculty of Political Science, Zagreb \\ E-mail adress:giannalusa@yahoo.com
}

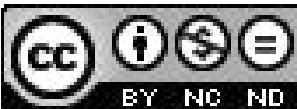

\begin{abstract}
The authors examine the effect of membership of small states in regional economic organizations and integrations on the growth of GDP. The aim is to use cost-benefit analysis to answer the question of whether small states, and also small economies, achieve greater economic growth through regional economic organizations and integrations than those small states that are not small economies. Small states, as the subjects of research work, have been chosen precisely because of their size, here defined by quantitative criteria, but taking into account that relational criteria are very important for their positioning in international relations, such as greater exposure to external influences and their dependence on membership in regional economic organizations and integrations. The GDP of small states, in an attempt to answer the hypothesis, was followed for a period of twenty years. Characteristics that depend on regional affiliation of small states, as well as the similarities and differences between small states which are members of the same regional economic organizations/ integrations, were also the subject of this paper.
\end{abstract}

Key words: small states, small economies, economic growth, regional economic organizations and integrations, gross domestic product (GDP).

\section{INTRODUCTORY CONSIDERATIONS}

The study of small states has always attracted the attention of the literary world due to the connotations tied to them, such as isolation, secrecy, leisurely and luxurious lifestyles, adventure. However, it was during the 60s and 70s of the past century that interest in their economic determinants and performance increased, based on the fact that the size of a country and its natural resources are important determinants of economic growth (Parsad, 2009, p. 44). In recent years, the economic approach to the study of small states was differentiated, seeing them as more fragmented due to economic determinants and categorizing the relation- 
ship between small and large states. In doing so, there is still a lack of economic analysis of the differential indicators among small states.

Thorhallsson addresses this inconsistency by proposing a new method of determining size and influence. He provides six categories when determining state size: (1) the fixed size of the state; (2) whether a state can actually maintain its own sovereignty at the international level; (3) a state's political size, including military and administrative capabilities, internal cohesion and external unity; (4) its economic size; (5) how the state is viewed by actors both domestic and foreign; and (6) the views of the governing elite regarding the possibilities and priorities of the state internationally (Thorhallson, 2006, p. 8-14).

Small states are different in a large number of aspects, especially with regard to the degree of vulnerability to changes in their external environment. A large number of small states formed regional integration agreements (RIAs) such as CARICOM (Caribbean Community and Common Market) and the OECS (the Organization of Eastern Caribbean States), which allow preferential trade access to member states, but at the same time maintain an unaltered external trade policy toward the rest of the world, thereby resulting in reduced profits of the entire block (Schiff, 1997). Large member states benefit more than smaller states from such arrangements. One of the reasons is that former have positive results in their trade with small states. Namely, larger and more developed countries attempt to produce protected products that will be competitive, compared to imports from the rest of the world, which have a common external customs tariff. Within the framework of regional economic organizations and integrations they sell their products without customs to small states, resulting in the transfer of customs revenue from poorer to richer countries. Still, small member states of Southern RIAs can benefit from a reduction of common foreign trade barriers, and gain visibility and recognition in terms of holding international negotiations (Schiff, 2002). Thus, such regional economic organizations and integrations can result in the strengthening of a climate of trust, on the one hand, and tensions in cases where the distribution of benefits and costs is asymmetric, on the other. The economic performance of small states within the framework of regional organizations and integrations depends on that, and it can be further analyzed with respect to differences between large and small member states, as well as between small states and small states that are also small economies.

Economic theory defines that small states have intrinsic defects (Easterly, \& Kraay, 2000; Alesina, \& Spolaore, 2003). Specifically, problems they are facing range from the determinants of geographical position, natural disasters, and relatively open markets, to the surplus of exports over imports. According to Aiyar (2008), there are three key determinants that affect the economic performance of small states - geographic location, natural resources, policies and institutions. Given their geography, small states are mostly islands or landlocked, which carries with it a number of deficiencies that vary regionally. Furthermore, natural resources (such as oil) are extremely important for the economic prosperity of small states, and changing policies and institutions can minimize the disadvantages of the first two categories, and maximize the benefits. Examples of small states 
that have succeeded in just that are Antigua and Barbuda, the Bahamas, Barbados, Mauritius and Botswana (Aiyar, 2008).

On the other hand, Ramkissoon (2002) believes that the measuring of economic performance of small states is based on the constraints arising from the size itself, such as small internal markets, limited opportunities for development of endogenous technologies, limited quality of natural resources, the narrow structure of import and export markets, high transportation costs, and high dependence on strategic imports. Significant differences in performance were observed among small states. Therefore, the author introduces a number of factors affecting the interpretation of growth of small economies: geography (island location, climate, location in relation to other countries, distance from the equator); strategic importance (e.g. location along an important strategic route); degree of vulnerability; political stability (political environment of relative peace); natural resources; openness to international trade in goods and services; economic structure (the strengthening of certain economic sectors such as tourism and financial services); cultural and social coherence (strong sense of community, a greater elasticity of social institutions); independence and endogenous policies (fast and flexible responses to external shocks and targeted specialization) (Armstrong, \& Read, 2000).

Small states are more vulnerable to international economic fluctuations given the openness of their economy, and are dependent on a number of economic activities, which all results in greater volatility of GDP compared to large states (Armstrong, \& Read, 1998). Namely, they seek specialization in order to be internationally competitive, and often rely on one or two export products. Furthermore, their export is concentrated on specific markets. Therefore, small states are the first to feel the effects of an international economic crisis (Handel, 1981), which also affects them the fastest with the deepest effects.

Recent empirical evidence (Luthria \& Dhat, 2005) gave additional credibility to specific problems faced by small states, proving that there is a price to pay for size, which is manifested in higher transportation costs of imports and exports, higher utility costs, as well as extensive business costs. These are the consequences of market size, location as well as politics.

Briguglio, Persuad and Stern (2005) suggest several ways in which small states can deal with their shortcomings: through the diversification of activities that are sustainable in the long term (especially services, notably tourism, which converts geographic disadvantages such as difficult access and distance into benefits), investments in telecommunications services, as well as regional approaches that allow them additional investments into government services, infrastructure and human development. Also small states can be the first to recover from an economic crisis considering that their small bureaucracy, with shorter distances between decision-makers and faster decision-making, affects a quicker adaptation to the situation (Kautto, 2001). To offset their economic vulnerability small states look for protection from large neighbors and the auspices of international and regional organizations in which they benefit from clear procedures and rules. Further reasons for the success of small states are a high level of structural trade openness, which requires them to carry out an export-driven growth strategy based on their comparative 
advantages, strategies filling a niche in the form of use of natural resources and human capital intensive activities; location, while keeping in mind the additional risks from accession into larger regional and global markets due to their distance; the successful use of limited circuits of politics, cultural diversity and social capital in the form of building networks of trust and norms of reciprocity (Armstrong, \& Read, 2004).

Easterly and Kraay (2000) point out that small states have a higher GNI (Gross National Income) per capita than larger ones, and the differences among the countries in this group are more drastic than the average difference between small and large states. This also demonstrates that size is not a key factor in economic performance. The same study emphasized that market openness and large trading range, which is a perceived as a handicap of small states due to economic volatility, are also advantageous in terms of GDP growth.

According to the results of the research small states have higher incomes and higher levels of productivity than larger ones, and their economies do not grow slower than the large economies (Easterly, \& Kraay, 2000). For example, none of the small Caribbean and Pacific States is a low income state. Astonishing results are found in Africa, where small states are, on average, four times wealthier than the large countries, while a relatively small number of small states are poor and heavily indebted. Of the 41 countries monitored by the Heavily Indebted Poor Countries Initiative there are only five small states (Aiyar, 2008). A study by Winters and Martins (2004) points out that large and small states have comparable policies and institutions, and CPIA (Country Policy and Institution Assessment) indicates that a small state compared to larger one leads in financial stability, banking regulations, the business regulatory environment, transparency and property rights.

Other advantages of small over large states are as follows: relatively homogenous population, small island states are less open to violence flow and other fluctuations from neighboring countries, small states benefit from specializing in niches such as military bases, philately, telecommunication services, offshore business, renting services, fishing rights, tourism etc. (Aiyar, 2008). On the other hand large states are more autonomous in formulating and conducting of their foreign policy, which is mostly described as proactive, while small states are more reactive in their foreign policy behavior in terms of being more constrained and affected by the international environment. Furthermore small states develop different foreign policy strategies some of which is bandwagoning with, rather then balancing against great powers; they are economically more dependent, their foreign policy is mostly focused on joining international and regional organizations (multilateralism) as well on their relations with neighboring countries; they are less influential in regional organizations (e.g. EU) compared to larger states who have greater economic weight, more voting power in the Council of Ministers and can sometimes make side-deals outside the formal decision-making process. It is easy for them to be invisible in international politics (quietism) by adopting a position of a bystander. Small states must therefore change their traditional reactive policy focused on bandwagoning and quietism to a proactive smart state strategy by playing their role as lobbyists, coalition builders, mediators and norm entre- 
preneurs if they want to punch above their weights in international politics and establish themselves as small powers.

Regardless of the fact that small states face common external and internal challenges, some still achieve better results. However, the measuring of economic performance of small states itself is not simple. In the case of small Caribbean states, despite similarities in their socio-economic and political evolution, their performance, as measured by changes in average GDP per capita in the twenty-year period, showed that the smaller islands have achieved better results than the larger ones. In doing so, the key was building the institutional infrastructure, as well as their openness and economic structure, with an emphasis on tourism and offshore finance, political stability, and cultural and social cohesion (while factors such as geography and natural resources are structural and hence less susceptible to control) (Ramkissoon, 2002). Given the lack of research dedicated to the economic performance of small states, especially their differentiation into small states and small states which are also small economies, and the impact of regional economic organizations and integrations on the indicators mentioned, the main goal of this paper is to answer two hypotheses:

- Do small states which are also small economies ${ }^{1}$, achieve faster economic growth in the same period, measured by GDP in time, within the same regional economic organizations and integrations, than small states that are not small economies?

- Are there regional differences in economic growth, measured by the increase of the total GDP in time, among small states? Small states who are also small economies and those who are not were taken into account here as well.

When searching for answers to these questions, first and foremost:

- the quantitative criteria for singling out small states were accurately set;

- the arguments for using these exact criteria were laid out;

- the mentioned states were singled out according to the set criteria.

The GDP of small states was followed in a twenty-year period (1993-2012), to determine its trajectory. Small states were then classified by regional economic organizations and integrations, in order to determine the similarities and differences between the states that are members of the same organization/integration, and states that are not members of the same organization/integration.

Small states, as subjects of research, have been chosen precisely because of their size, here defined by quantitative criteria, bearing in mind that for their positioning in international relations the relational criteria are extremely important, such as, for example, their total GDP compared to the GDP of larger countries, and the fact that they represent a group of countries that are more exposed to external influences and more dependent on joining regional economic organizations and integrations. The paper also attempts to identify the characteristics that depend on the regional affiliation of small states, as well as the similarities and differences between small states which belong to the same regional economic organization/integration.

Small economies are those with GDP in Current US \$ bellow 15 billion in 2012 (as the last year of reference), regardless the population size. 


\section{DEFINING SMALL STATES: METHODOLOGY AND RESULTS}

In the literature devoted to small states, there are different criteria for their definition. Political geography as a discipline of geographic science, often takes into account the surface area of a country. Scientific disciplines such as political science or economics, dealing with issues such as international relations, international economics, etc., take the number of inhabitants as the criterion for classifying a country as small. Small states, which are defined as such based on population, are the subject of study in political science and economics literature, but also of the interest of international organizations and integrations (Kurečić 2012, p. 90). States with a small surface area size and a small population have specificity that arises precisely from the fact that they have a small population and a small surface area.

Singling out small states should take into account the fact that although there is a consensus that small states certainly exist as a specificity and a concept, there is absolutely no consensus on the exact criteria and requirements that a country must meet to be considered a small state. Thus, a classification of small states mostly boils down to this - as many authors, as many different criteria and thus classifications of small states. Recognizing the abundance and diversity of criteria for the classification of small states - quantitative, qualitative and relational (Hanggi, \& Regnier, 2000, p. 7) - for reasons of exactness we have decided to use the quantitative criteria for classifying small states, in order to correctly (by using figures) define which countries will be discussed, taking exceptions into account ${ }^{2}$. Hey (2003, p. 3), however, believes that insisting only on quantitative criteria produces too many exceptions, but here the exceptions are debated on as just that exceptions, separately, with emphasis on why each case is an exception, and the effects such an exceptional position produces.

The classification of small states on the basis of two quantitative criteria, size and population, done by Kurečić (2012, pp. 97-103), applying as limits the surface area of 60,000 square kilometers and a population of four million, has been taken as a guideline for the minimum number of exceptions, which is direct a result of the set limits in size and population, because different limits would produce more exceptions. In this study, a total of 73 countries meet the criteria when it comes to surface area criterion, and 71 countries that meet the criteria when it comes to population were identified. At the same time, 57 small states that meet both criteria that were applied were singled out.

For the purposes of this study, which has an economic dimension, the total GDP with a set limit of US $\$ 15$ billion was added as a third criterion to size and population, while using the total GDP in relation to the current US\$, which more faithfully reflects the position of one economy compared to other economies

2 In case of defining small states by using quantitative criteria one needs to take into account their limitations. Despite their exactness, some things cannot be measured and numbered, such as state's self-perception, which makes a basis of qualitative criteria and state's relations in the international community, which are being covered by relational criteria. However these defining criteria as well as discussion on their limitation are not the topic of this article: discussion on criteria is intended only to elaborate why some criteria for distinguishing different groups of small states where chosen. 
(instead of the Purchasing Power Parity that measures the purchasing power of the population). The limit of US $\$ 15$ billion is one below which the economy of a country, for the purposes of this paper, can be considered small. GDP, as a third criterion, was added precisely to attempt to define small states more accurately, since countries can be small in one sense, and not in the other. Rapaport (1971: 29) adds more criteria to defining small states by combining population and size or population, size and GDP. Namely a small sized state with small population can be economically developed and very influential (e.g. Switzerland, Singapore, Luxemburg) and if there is also a respectful military power (e.g. Israel) it can be considered also a small power. Its position in international relations seems to be quite different from other small states that are more vulnerable to external influences and more dependent on other countries. There are several strategies which can position small states as proactive smart states: coalition building, use of soft power, norm entrepreneuring, honest brokering and identifying strategic priorities.

States that meet the criteria of small surface areas, a small population and a small total GDP, were analyzed along with the exceptions that do not meet one or two of the three criteria. From countries that meet none of the three criteria, the exceptions that would colloquially be called area-wise, population-wise or economic "giants" among small states were isolated. At the same time, as an exception, countries that represent true "economic dwarfs", i.e., those that do not belong among small states by surface area or population according to the applied criteria, but whose total GDP puts them in the group of small countries, that is, small economies were singled out. Research studies of the impact of involvement in regional organizations/integrations on the growth of GDP, focused precisely on small economies, i.e. those below US\$ 15 billion of total GDP in 2012, and compared them to larger economies, where again, it should be taken into consideration that the ratio between the size of economies of individual countries (which can be considered small under one of the three criteria and have economies that have achieved over 15 billion US\$ of GDP in 2012) can amount to 1:50 as a result of an extremely large difference in the level of GDP per capita. Precisely because of the huge difference in size between the economies of small states that meet the set criteria, the research also included those small states that meet all the criteria and the ones that do not meet the GDP criterion, in an attempt to discover the differences in economic growth between these two heterogeneous groups of countries regarding their GDP.

Looking at Table 1, it is evident that there are a total of 46 states that meet all three criteria and can be considered small states according to their surface area, their population, and the size of their total GDP. And this 46 countries can be divided into several subgroups. The surfaces of these countries vary from 0.44 square kilometers (Vatican City) up to 38,394 square kilometers (Bhutan), the population ranges from 839 (Vatican City) to 3,619,925 (Molodova), while the size of GDP varies from 38 million US\$ for Tuvalu to 14,840 million US \$ for Jamaica. Classification set forth herein is considered useful as it clearly separates the states that meet all three criteria from exceptions that do not meet some of these criteria. 
Table 1. Small states that meet the criteria of small surface area, small population and small total GDP: surface area and population (estimated in 2013), total GDP in Current US\$ and BDP per capita /PPP/(2012).

\begin{tabular}{|c|c|c|c|c|}
\hline State & $\begin{array}{l}\text { Surface } \\
\text { area in } \\
\text { square } \\
\text { kilome- } \\
\text { ters }\end{array}$ & $\begin{array}{l}\text { Popula- } \\
\text { tion (Ac- } \\
\text { cording to: } \\
\text { The World } \\
\text { Factbook. } \\
\text { Country } \\
\text { Comparison: } \\
\text { Population) }\end{array}$ & $\begin{array}{l}\text { Total GDP } \\
\text { in mil. US\$ / } \\
\text { Current US\$/ } \\
\text { (The World } \\
\text { Bank Data- } \\
\text { bank: GDP } \\
\text { (current } \\
\text { US\$))) }\end{array}$ & $\begin{array}{l}\text { GDP per capita } \\
\text { in US\$ /PPP/ } \\
\text { (The World } \\
\text { Factbook. } \\
\text { Country Com- } \\
\text { parison: GDP } \\
\text { (Purchasing } \\
\text { Power Parity)) }\end{array}$ \\
\hline - Albania & 28,748 & $3,011,405$ & 13,119 & 8,200 \\
\hline - Andorra & 468 & 85,293 & 4,800 & 37,200 \\
\hline $\begin{array}{l}\text { - Antigua and } \\
\text { Barbuda }\end{array}$ & 443 & 90,156 & $1,176^{*}$ & 18,300 \\
\hline - Armenia & 29,743 & $2,974,184$ & 9,910 & 5,900 \\
\hline - Bahamas, The & 13,880 & 319,031 & $8,149^{*}$ & 31,900 \\
\hline - Barbados & 430 & 288,725 & 4,490 & 25,800 \\
\hline - Belize & 22,966 & 334,297 & $1,554^{*}$ & 8,900 \\
\hline - Bhutan & 38,394 & 725,296 & 1,780 & 6,800 \\
\hline - Cape Verde & 4,033 & 531,046 & 1,897 & 4,200 \\
\hline - Comoros, The & 2,235 & 752,288 & 596 & 1,300 \\
\hline - Djibouti & 23,200 & 792,198 & $1,354^{*}$ & 2,700 \\
\hline - Dominica & 751 & 73,286 & 480 & 14,400 \\
\hline - Fiji & 18,274 & 896,758 & 3,882 & 4,900 \\
\hline - Gambia, The & 11,295 & $1,883,051$ & 917 & 1,900 \\
\hline - Grenada & 344 & 109,590 & 790 & 13,700 \\
\hline - Guinea-Bissau & 36,125 & $1,660,870$ & 897 & 1,200 \\
\hline - Jamaica & 10,991 & $2,909,714$ & 14,840 & 9,300 \\
\hline - Kiribati & 811 & 103,248 & 176 & 6,100 \\
\hline - Kosovo & 10,887 & $1,847,708$ & 6,238 & 7,355 \\
\hline - Lesotho & 30,355 & $1,936,181$ & 2,448 & 2,200 \\
\hline - Liechtenstein & 160 & 37,009 & $5,113^{*}$ & 89,400 \\
\hline - Macedonia & 25,713 & $2,087,171$ & 9,663 & 10,800 \\
\hline - Maldives & 298 & 393,988 & 2,222 & 9,400 \\
\hline - Malta & 316 & 411,277 & 8,722 & 27,500 \\
\hline - Marshall Islands & 181 & 69,747 & 187 & 8,800 \\
\hline - Mauritius & 2,040 & $1,322,238$ & 10,492 & 15,800 \\
\hline $\begin{array}{l}\text { Micronesia, } \\
\text { Federated States } \\
\text { of }\end{array}$ & 702 & 106,104 & 327 & 7,500 \\
\hline - Moldova & 33,851 & $3,619,925$ & 7,254 & 3,500 \\
\hline - Monaco & 2 & 30,500 & $5,748^{3 *}$ & 70,700 \\
\hline
\end{tabular}

* https://www.cia.gov/library/publications/the-world-factbook/rankorder/2001rank.html

** Nauru's data are from 2005., while no data for the Vatican City. 


\begin{tabular}{|c|c|c|c|c|}
\hline State & $\begin{array}{l}\text { Surface } \\
\text { area in } \\
\text { square } \\
\text { kilome- } \\
\text { ters }\end{array}$ & $\begin{array}{l}\text { Popula- } \\
\text { tion (Ac- } \\
\text { cording to: } \\
\text { The World } \\
\text { Factbook. } \\
\text { Country } \\
\text { Comparison: } \\
\text { Population) }\end{array}$ & $\begin{array}{l}\text { Total GDP } \\
\text { in mil. US\$ / } \\
\text { Current US\$/ } \\
\text { (The World } \\
\text { Bank Data- } \\
\text { bank: GDP } \\
\text { (current } \\
\text { US\$))) }\end{array}$ & $\begin{array}{l}\text { GDP per capita } \\
\text { in US\$/PPP/ } \\
\text { (The World } \\
\text { Factbook. } \\
\text { Country Com- } \\
\text { parison: GDP } \\
\text { (Purchasing } \\
\text { Power Parity)) }\end{array}$ \\
\hline - Montenegro & 13,812 & 653,474 & 4,231 & 12,000 \\
\hline - Nauru & 21 & 9,434 & $60 * *$ & $5,000^{*}$ \\
\hline - Palau & 459 & 21,108 & 228 & 10,500 \\
\hline $\begin{array}{l}\text { - Saint Kitts and } \\
\text { Nevis }\end{array}$ & 261 & 51,134 & 748 & 16,500 \\
\hline - Saint Lucia & 616 & 162,781 & 1,186 & 13,300 \\
\hline $\begin{array}{l}\text { - Sao Tome and } \\
\text { Principe }\end{array}$ & 964 & 186,817 & 264 & 2,400 \\
\hline $\begin{array}{l}\text { - Saint Vincent and } \\
\text { the Grenadines }\end{array}$ & 389 & 103,220 & 713 & 12,000 \\
\hline - Samoa & 2,831 & 195,476 & 677 & 6,300 \\
\hline - San Marino & 61 & 32,448 & $1,855^{*}$ & 36,200 \\
\hline - Seychelles & 455 & 90,846 & 1,032 & 25,600 \\
\hline - Solomon Islands & 28,896 & 597,248 & 1,008 & 3,400 \\
\hline - Swaziland & 17,364 & $1,403,362$ & 3,747 & 5,900 \\
\hline - Timor-Leste & 14,874 & $1,172,390$ & 1,293 & 10,000 \\
\hline - Tonga & 747 & 106,322 & 472 & 7,700 \\
\hline - Tuvalu & 26 & 10,698 & 37 & 3,400 \\
\hline - Vanuatu & 12,189 & 262,565 & 785 & 5,000 \\
\hline - Vatican City & 0,44 & 839 & $\mathrm{NA}^{* *}$ & $\mathrm{NA}^{* *}$ \\
\hline
\end{tabular}

Source: The Authors, The World Bank Databank: GDP (current US\$). Retrieved from https://www. data.worldbank.org/indicator/NY.GDP.MKTP.CD; The World Factbook. Country Comparison: GDP (Purchasing Power Parity) https://www.cia.gov/library/publications/the-world-factbook/rankorder/2001rank.html; The World Factbook. Country Comparison: Population, Retrieved from https://www. cia.gov/library/publications/the-world-factbook/rankorder/2119rank.html

Table 2. Small states that don't meet one or two out of three set criteria of small surface area, small population and small total GDP: surface area and population (estimated in 2013), total GDP in Current US\$ and BDP per capita / PPP/(2012).

\begin{tabular}{|l|r|r|r|l|}
\hline State & $\begin{array}{l}\text { Surface } \\
\text { area in } \\
\text { square } \\
\text { kilome- } \\
\text { ters }\end{array}$ & $\begin{array}{l}\text { Population (Ac- } \\
\text { cording to: The } \\
\text { World Factbook. } \\
\text { Country Com- } \\
\text { parison: Popula- } \\
\text { tion) }\end{array}$ & $\begin{array}{l}\text { Total GDP in } \\
\text { mil. US\$/Cur- } \\
\text { rent US\$/ } \\
\text { (The World } \\
\text { Bank Databank: } \\
\text { GDP(current } \\
\text { US\$)) }\end{array}$ & $\begin{array}{l}\text { GDP per capita } \\
\text { in US\$/PPP/ } \\
\text { (The World Fact- } \\
\text { book. Country } \\
\text { Comparison: } \\
\text { GDP (Purchasing } \\
\text { Power Parity)) }\end{array}$ \\
\hline - Bahrain & 760 & $1,281,332$ & 27,030 & 29,200 \\
\hline - Belgium & 30,528 & $10,444,268$ & 483,700 & 38,500 \\
\hline - Benin & 112,622 & $9,877,292$ & 7,557 & 1,700 \\
\hline
\end{tabular}




\begin{tabular}{|c|c|c|c|c|}
\hline State & $\begin{array}{l}\text { Surface } \\
\text { area in } \\
\text { square } \\
\text { kilome- } \\
\text { ters }\end{array}$ & $\begin{array}{l}\text { Population (Ac- } \\
\text { cording to: The } \\
\text { World Factbook. } \\
\text { Country Com- } \\
\text { parison: Popula- } \\
\text { tion) }\end{array}$ & $\begin{array}{l}\text { Total GDP in } \\
\text { mil. US\$/Cur- } \\
\text { rent US\$/ } \\
\text { (The World } \\
\text { Bank Databank: } \\
\text { GDP (current } \\
\text { US\$))) }\end{array}$ & $\begin{array}{l}\text { GDP per capita } \\
\text { in US\$/PPP/ } \\
\text { (The World Fact- } \\
\text { book. Country } \\
\text { Comparison: } \\
\text { GDP (Purchasing } \\
\text { Power Parity)) }\end{array}$ \\
\hline $\begin{array}{ll}\text { - } & \text { Bosnia and } \\
& \text { Herzegovina }\end{array}$ & 51,197 & $3,875,723$ & 17,048 & 8,400 \\
\hline - Botswana & 581,730 & $2,127,825$ & 14,411 & 17,100 \\
\hline - Brunei & 5,765 & 415,717 & 16,954 & 55,300 \\
\hline - Burkina Faso & 274,200 & $17,812,961$ & 10,441 & 1,400 \\
\hline - Burundi & 27,830 & $10,888,321$ & 2,472 & 600 \\
\hline - Cambodia & 181,035 & $15,205,539$ & 14,062 & 2,400 \\
\hline $\begin{array}{l}\text { - Central Afri- } \\
\text { can Republic }\end{array}$ & 622,984 & $5,166,510$ & 2,139 & 800 \\
\hline - Chad & $1,284,000$ & $11,193,452$ & 11,018 & 2,000 \\
\hline $\begin{array}{l}\text { Congo, Re- } \\
\text { public of the }\end{array}$ & 342,000 & $4,492,689$ & 13,678 & 4,700 \\
\hline - Costa Rica & 51,100 & $4,695,942$ & 45,127 & 12,800 \\
\hline - Croatia & 56,594 & $4,290,611$ & 56,442 & 18,100 \\
\hline - Cyprus & 9,251 & $1,155,403$ & 22,981 & 27,500 \\
\hline - Denmark & 43,096 & $5,556,452$ & 314,242 & 38,300 \\
\hline $\begin{array}{l}\text { Dominican } \\
\text { Republic }\end{array}$ & 48,670 & $10,219,630$ & 58,951 & 9,800 \\
\hline - El Salvador & 21,041 & $6,108,590$ & 23,787 & 7,600 \\
\hline $\begin{array}{l}\text { - Equatorial } \\
\text { Guinea }\end{array}$ & 28,051 & 704,001 & 17,697 & 26,400 \\
\hline - Eritrea & 117,600 & $6,233,682$ & 3,092 & 800 \\
\hline - Estonia & 45,228 & $1,266,375$ & 21,854 & 22,100 \\
\hline - Gabon & 267,667 & $1,640,286$ & 18,661 & 16,800 \\
\hline - Guinea & 245,857 & $11,176,026$ & 6,768 & 1,100 \\
\hline - Guyana & 214,969 & 739,903 & 2,851 & 8,100 \\
\hline - Haiti & 27,750 & $9,893,934$ & 7,843 & 1,300 \\
\hline - Iceland & 103,000 & 315,281 & 13,657 & 39,900 \\
\hline - Israel & 20,770 & $7,707,042$ & 240,900 & 32,800 \\
\hline - Kuwait & 17,818 & $2,695,316$ & 173,400 & 40,500 \\
\hline - Kyrgyzstan & 199,951 & $5,548,042$ & 6,473 & 2,400 \\
\hline - Laos & 236,800 & $6,695,166$ & 9,299 & 3,100 \\
\hline - Latvia & 64,589 & $2,178,443$ & 28,374 & 18,600 \\
\hline - Lebanon & 10,400 & $4,131,583$ & 42,945 & 16,000 \\
\hline - Liberia & 111,369 & $3,989,703$ & 1,767 & 700 \\
\hline - Lithuania & 65,300 & $3,515,858$ & 42,246 & 22,000 \\
\hline - Luxembourg & 2,586 & 514,862 & 57,117 & 81,100 \\
\hline
\end{tabular}




\begin{tabular}{|c|c|c|c|c|}
\hline State & $\begin{array}{l}\text { Surface } \\
\text { area in } \\
\text { square } \\
\text { kilome- } \\
\text { ters }\end{array}$ & $\begin{array}{l}\text { Population (Ac- } \\
\text { cording to: The } \\
\text { World Factbook. } \\
\text { Country Com- } \\
\text { parison: Popula- } \\
\text { tion) }\end{array}$ & $\begin{array}{l}\text { Total GDP in } \\
\text { mil. US\$/Cur- } \\
\text { rent US\$/ } \\
\text { (The World } \\
\text { Bank Databank: } \\
\text { GDP (current } \\
\text { US\$))) }\end{array}$ & $\begin{array}{l}\text { GDP per capita } \\
\text { in US\$/PPP/ } \\
\text { (The World Fact- } \\
\text { book. Country } \\
\text { Comparison: } \\
\text { GDP (Purchasing } \\
\text { Power Parity)) }\end{array}$ \\
\hline - Madagascar & 587,041 & $22,599,098$ & 9,975 & 1,000 \\
\hline - Malawi & 118,484 & $16,777,547$ & 4,264 & 900 \\
\hline - Mali & $1,240,192$ & $15,968,882$ & 10,308 & 1,100 \\
\hline - Mauritania & $1,030,700$ & $3,437,610$ & 4,199 & 2,200 \\
\hline - Mongolia & $1,564,116$ & $3,226,516$ & 10,271 & 5,500 \\
\hline - Namibia & 824,292 & $2,182,852$ & 12,807 & 7,900 \\
\hline - Netherlands & 41,543 & $16,805,037$ & 772,227 & 42,900 \\
\hline - Nicaragua & 130,370 & $5,788,531$ & 10,507 & 4,500 \\
\hline - Niger & $1,267,000$ & $16,899,327$ & 6,568 & 800 \\
\hline - Oman & 309,500 & $3,154,134$ & 76,460 & 29,600 \\
\hline - Panama & 75,420 & $3,559,408$ & 36,253 & 15,900 \\
\hline - Qatar & 11,586 & $2,042,444$ & 183,400 & 103,900 \\
\hline - Rwanda & 26,338 & $12,012,589$ & 7,103 & 1,500 \\
\hline - Senegal & 196,722 & $13,300,410$ & 14,160 & 2,100 \\
\hline - Sierra Leone & 71,740 & $5,612,685$ & 3,796 & 1,400 \\
\hline - Singapore & 697 & $5,460,302$ & 274,701 & 61,400 \\
\hline - Slovakia & 49,035 & $5,488,339$ & 91,619 & 24,600 \\
\hline - Slovenia & 20,273 & $1,992,690$ & 45,469 & 28,700 \\
\hline - Somalia & 637,657 & $10,251,568$ & 2,372 & 600 \\
\hline - South Sudan & 644,329 & $11,090,104$ & 9,337 & 1,000 \\
\hline - Suriname & 163,820 & 566,846 & 4,738 & 12,600 \\
\hline - Switzerland & 41,227 & $7,996,026$ & 632,194 & 46,200 \\
\hline - Tajikistan & 143,100 & $7,910,041$ & 6,987 & 2,300 \\
\hline - Togo & 56,785 & $7,154,237$ & 3,814 & 1,100 \\
\hline $\begin{array}{l}\text { - } \begin{array}{l}\text { Trinidad and } \\
\text { Tobago }\end{array} \\
\text { Tobat }\end{array}$ & 5,128 & $1,225,225$ & 23,986 & 20,400 \\
\hline - Uruguay & 163,820 & $3,324,460$ & 49,060 & 16,200 \\
\hline - Zimbabwe & 390,757 & $13,182,908$ & 10,814 & 600 \\
\hline
\end{tabular}

Looking at the Table 2 there are 62 states that do not meet one or two specified criteria applied to small states. These states can, to some extent, be divided into subgroups according to the level of economic development measured by total GDP and GDP per capita, which is useful in order to highlight their common features as well as regional grouping of states which share similar features. This division ignores surface area having in mind that physical size of the country doesn't have a direct impact on the size of the economy:

- $\quad$ states with the population over 4 million and GDP up to 15 billion US\$ representing small economies (Benin, Burkina Faso, Burundi, Cambodia, Cen- 
tral African Republic, Chad, Republic of the Congo, Eritrea, Guinea, Haiti, Kyrgyzstan, Laos, Madagascar, Malawi, Mali, Nicaragua, Niger, Rwanda, Senegal, Sierra Leone, Somalia, South Sudan, Tajikistan, Togo, Zimbabwe). These states, with the exception of the Republic of Congo and Nicaragua, are among the least developed countries in the world and are mostly found in Africa, Asia and the region of Central America and Caribbean.

- states with the population up to 4 million and GDP up to 15 billion US\$ representing exceptions because of the surface area greater than 60000 square kilometers (Botswana, Guyana, Iceland, Liberia, Mauritania, Mongolia, Namibia and Suriname). They present a diverse group of countries without strong common characteristic except from an extremely low population density.

- states with the population up to 4 million and GDP over 15 billion US\$ (Bahrain, Bosnia and Herzegovina, Brunei, Cyprus, Equatorial Guinea, Gabon, Estonia, Kuwait, Latvia, Lithuania, Luxembourg, Oman, Panama, Qatar, Slovenia, Trinidad and Tobago, Uruguay). These states are medium or highly developed, located on different continents (except North America and Australia) and their surface area is significantly distinctive, which indicates their population density being also different.

- states with the population over 4 million and GDP over 15 billion US\$ (Belgium, Costa Rica, Croatia, Denmark, Dominican Republic, El Salvador, Israel, Lebanon, Netherlands, Singapore, Slovakia, Switzerland). These states are medium or highly developed and located in Europe, Central America and Asia.

From this division of states that do not meet one or two criteria set for defining small states, it is evident that they can be classified into one group of less developed states, one group of middle and high developed stats, as well as into one group that comprises states of all different levels of development. This division just aims to detect generalization among different states out of the same group of 62 states, always taking into account two (population and total GDP) parameters. There is a total of 108 small states that meet all three criteria or do not meet one or two criteria, while there are 79 small economies according to GDP criteria.

After the classification of small states, a categorization was made of most of the small states that meet all the criteria and small states that do not meet one or two criteria in Table 3, according to individual regional economic organizations or integrations.

The countries which are not members of a common regional economic organization or integration, which would have had a very significant impact on their economies, were regionally categorized. Those organizations in which there are small states, but no small economies, such as the Gulf Cooperation Council (GCC) were taken into account. The Pacific Islands Forum (PIF), in which all the members are small states and also small economies, was considered. Countries that are members of a regional economic organization in which there are no other small states, as in the case of Uruguay and Bhutan, were not taken into account. The years 1993 (20 years before the last reference year), 2008 (for most of the resear- 
ched economies the year of the highest GDP, before entering into recession) and 2012 (the last year for which data is available) were taken as reference years. If the data for one of the reference years was unavailable, the closest year for which data was available was taken, using the same source, as indicated in Table 3.

Table 3. Small economies (with total GDP below 15 mil.US\$ in 2012) according to individual regional economic organization or integration: GDP in Current US\$ for 1993, 2008 i 2012, with indexes.

European Union, 12 small states (plus 16 member states which are not defined as small)

\begin{tabular}{|c|c|c|c|}
\hline State & Year & GDP in mil. US\$ & GDP - index \\
\hline Belgium & $\begin{array}{l}1993 \\
2008 \\
2012\end{array}$ & $\begin{array}{l}221986 \\
507379 \\
483709\end{array}$ & $\begin{array}{l}100.0 \\
228.6 \\
217.9\end{array}$ \\
\hline Croatia & $\begin{array}{l}1993 \\
2008 \\
2012\end{array}$ & $\begin{array}{l}10901 \\
69595 \\
56442\end{array}$ & $\begin{array}{l}100.0 \\
638.4 \\
517.8\end{array}$ \\
\hline Cyprus & $\begin{array}{l}1993 \\
2008 \\
2012 \\
\end{array}$ & $\begin{array}{c}6590 \\
25321 \\
22981 \\
\end{array}$ & $\begin{array}{l}100.0 \\
384.2 \\
348.7\end{array}$ \\
\hline Denmark & $\begin{array}{l}1993 \\
2008 \\
2012 \\
\end{array}$ & $\begin{array}{l}140627 \\
343881 \\
314242\end{array}$ & $\begin{array}{l}100.0 \\
244.5 \\
223.5\end{array}$ \\
\hline Estonia & $\begin{array}{l}1995 \\
2008 \\
2012 \\
\end{array}$ & $\begin{array}{c}3777 \\
23782 \\
21854 \\
\end{array}$ & $\begin{array}{l}100.0 \\
629.7 \\
578.6 \\
\end{array}$ \\
\hline Latvia & $\begin{array}{l}1993 \\
2008 \\
2012 \\
\end{array}$ & $\begin{array}{c}4468 \\
33669 \\
28374 \\
\end{array}$ & $\begin{array}{l}100.0 \\
753.6 \\
635.0\end{array}$ \\
\hline Lithuania & $\begin{array}{l}1993 \\
2008 \\
2012\end{array}$ & $\begin{array}{c}7425 \\
47253 \\
42245\end{array}$ & $\begin{array}{l}100.0 \\
636.4 \\
569.0\end{array}$ \\
\hline Luxembourg & $\begin{array}{l}1993 \\
2008 \\
2012 \\
\end{array}$ & $\begin{array}{l}15788 \\
54743 \\
57117 \\
\end{array}$ & $\begin{array}{l}100.0 \\
346.7 \\
361.8 \\
\end{array}$ \\
\hline Malta & $\begin{array}{l}1993 \\
2008 \\
2012\end{array}$ & $\begin{array}{l}2709 \\
8554 \\
8722\end{array}$ & $\begin{array}{l}100.0 \\
315.8 \\
321.2\end{array}$ \\
\hline Netherlands & $\begin{array}{l}1993 \\
2008 \\
2012\end{array}$ & $\begin{array}{l}327495 \\
870811 \\
772226\end{array}$ & $\begin{array}{l}100.0 \\
265.9 \\
235.8\end{array}$ \\
\hline Slovakia & $\begin{array}{l}1993 \\
2008 \\
2012 \\
\end{array}$ & $\begin{array}{l}16146 \\
97909 \\
91219\end{array}$ & $\begin{array}{l}100.0 \\
606.4 \\
565.0\end{array}$ \\
\hline Slovenia & $\begin{array}{l}1993 \\
2008 \\
2012 \\
\end{array}$ & $\begin{array}{l}12673 \\
54606 \\
45469\end{array}$ & $\begin{array}{l}100.0 \\
430.9 \\
358.8\end{array}$ \\
\hline
\end{tabular}


Small states in Europe out of the integration process/neutrals

\begin{tabular}{|c|c|c|c|}
\hline State & Year & GDP in mil. US\$ & GDP-index \\
\hline Andorra & 1993 & 1007 & 100.0 \\
& 2008 & 3712 & 368.6 \\
& 2012 & NA & $/$ \\
\hline Iceland & 1993 & 6126 & 100.0 \\
& 2008 & 16832 & 274.8 \\
& 2012 & 13657 & 222.9 \\
\hline Liechtenstein & 1993 & 1673 & 100.0 \\
& 2008 & 4929 & 294.6 \\
& 2012 & NA & $/$ \\
\hline Monaco & 1993 & 2574 & 100.0 \\
& 2008 & 6919 & 268.8 \\
& 2011 & 6075 & 236.0 \\
\hline San Marino & 1999 & 853 & 100.0 \\
& 2008 & 1900 & 222.7 \\
& 2012 & NA & 1 \\
\hline Switzerland & 1993 & 249967 & 200.0 \\
& 2008 & 524289 & 252.9 \\
\hline
\end{tabular}

Small transitional countries in Western Balkans

\begin{tabular}{|c|c|c|c|}
\hline State & Year & GDP in mil. US\$ & GDP - index \\
\hline Albania & 1993 & 1228 & 100.0 \\
& 2008 & 12969 & 1056.1 \\
& 2012 & 13119 & 1068.3 \\
\hline Bosnia and Herzegovina & 1994 & 1256 & 100.0 \\
& 2008 & 18543 & 1476.4 \\
& 2012 & 17048 & 1357.3 \\
\hline Kosovo & 2000 & 1849 & 100.0 \\
& 2008 & 5642 & 305.1 \\
& 2012 & 6238 & 337.4 \\
\hline Macedonia & 1993 & 2550 & 100.0 \\
& 2008 & 9834 & 385.6 \\
& 2012 & 9663 & 378.9 \\
\hline Montenegro & 2000 & 984 & 100.0 \\
& 2008 & 4520 & 459.3 \\
& 2012 & 4231 & 430.0 \\
\hline
\end{tabular}

Small states of the Commonwealth of Independent States (CIS)

\begin{tabular}{|c|c|c|c|}
\hline State & Year & GDP in mil. US\$ & GDP - index \\
\hline Armenia & 1993 & 1201 & 100.0 \\
& 2008 & 11662 & 971.0 \\
& 2012 & 9910 & 807.0 \\
\hline Kyrgyzstan & 1993 & 2028 & 100.0 \\
& 2008 & 5140 & 253.5 \\
& 2012 & 6473 & 319.2 \\
\hline
\end{tabular}


Journal of Education Culture and Society No. 1_2014

\begin{tabular}{|c|c|c|c|}
\hline Moldova & 1993 & 2372 & 100.0 \\
& 2008 & 6055 & 255.3 \\
& 2012 & 7254 & 305.8 \\
\hline Tajikistan & 1993 & 1647 & 100.0 \\
& 2008 & 5161 & 313.4 \\
& 2012 & 6987 & 424.2 \\
\hline
\end{tabular}

Small states of the Carribean Community and Common Market (CARICOM)

\begin{tabular}{|c|c|c|c|}
\hline State & Year & GDP in mil. US \$ & GDP - index \\
\hline Antigua and Barbuda & $\begin{array}{l}1993 \\
2008 \\
2012 \\
\end{array}$ & $\begin{array}{c}457 \\
1347 \\
1176 \\
\end{array}$ & $\begin{array}{l}100.0 \\
294.7 \\
257.3\end{array}$ \\
\hline Bahamas, The & $\begin{array}{l}1993 \\
2008 \\
2012 \\
\end{array}$ & $\begin{array}{l}3092 \\
8247 \\
8149 \\
\end{array}$ & $\begin{array}{l}100.0 \\
266.7 \\
263.6 \\
\end{array}$ \\
\hline Barbados & $\begin{array}{l}1993 \\
2008 \\
2011 \\
\end{array}$ & $\begin{array}{l}1641 \\
3670 \\
3685 \\
\end{array}$ & $\begin{array}{l}100.0 \\
223.6 \\
224.6 \\
\end{array}$ \\
\hline Belize & $\begin{array}{l}1993 \\
2008 \\
2011 \\
\end{array}$ & $\begin{array}{c}560 \\
1364 \\
1448 \\
\end{array}$ & $\begin{array}{l}100.0 \\
243.6 \\
258.6\end{array}$ \\
\hline Dominica & $\begin{array}{l}1993 \\
2008 \\
2012 \\
\end{array}$ & $\begin{array}{l}200 \\
452 \\
480 \\
\end{array}$ & $\begin{array}{l}100.0 \\
226.0 \\
240.0\end{array}$ \\
\hline Grenada & $\begin{array}{l}1993 \\
2008 \\
2012 \\
\end{array}$ & $\begin{array}{l}250 \\
826 \\
790 \\
\end{array}$ & $\begin{array}{l}100.0 \\
330.4 \\
316.0\end{array}$ \\
\hline Guyana & $\begin{array}{l}1993 \\
2008 \\
2012 \\
\end{array}$ & $\begin{array}{c}442 \\
1923 \\
2851 \\
\end{array}$ & $\begin{array}{l}100.0 \\
435.1 \\
645.0\end{array}$ \\
\hline Haiti & $\begin{array}{l}1993 \\
2008 \\
2012 \\
\end{array}$ & $\begin{array}{l}1806 \\
6408 \\
7843 \\
\end{array}$ & $\begin{array}{l}100.0 \\
354.8 \\
434.3\end{array}$ \\
\hline Jamaica & $\begin{array}{l}1993 \\
2008 \\
2012 \\
\end{array}$ & $\begin{array}{c}4891 \\
13681 \\
14840\end{array}$ & $\begin{array}{l}100.0 \\
279.7 \\
303.4\end{array}$ \\
\hline Saint Kitts and Nevis & $\begin{array}{l}1993 \\
2008 \\
2012 \\
\end{array}$ & $\begin{array}{l}198 \\
736 \\
748 \\
\end{array}$ & $\begin{array}{l}100.0 \\
371.7 \\
377.8 \\
\end{array}$ \\
\hline Saint Lucia & $\begin{array}{l}1993 \\
2008 \\
2012 \\
\end{array}$ & $\begin{array}{c}492 \\
1165 \\
1186 \\
\end{array}$ & $\begin{array}{l}100.0 \\
236.8 \\
241.0\end{array}$ \\
\hline $\begin{array}{l}\text { Saint Vincent and the } \\
\text { Grenadines }\end{array}$ & $\begin{array}{l}1993 \\
2008 \\
2012 \\
\end{array}$ & $\begin{array}{l}239 \\
695 \\
713\end{array}$ & $\begin{array}{l}100.0 \\
290.8 \\
298.3\end{array}$ \\
\hline Suriname & $\begin{array}{l}1993 \\
2008 \\
2012 \\
\end{array}$ & $\begin{array}{c}429 \\
3533 \\
4738 \\
\end{array}$ & $\begin{array}{c}100.0 \\
823.5 \\
1104.4\end{array}$ \\
\hline
\end{tabular}




\begin{tabular}{|c|c|c|c|}
\hline Trinidad and Tobago & 1993 & 4585 & 100.0 \\
& 2008 & 28018 & 611.1 \\
& 2012 & 23986 & 523.1 \\
\hline
\end{tabular}

Central American Integration System (CACM), small states plus Guatemala and Honduras

\begin{tabular}{|c|c|c|c|}
\hline State & Year & GDP in mil. US\$ & GDP - index \\
\hline Belize & 1993 & 560 & 100.0 \\
& 2008 & 1364 & 243.6 \\
& 2011 & 1448 & 258.6 \\
\hline Costa Rica & 1993 & 9638 & 100.0 \\
& 2008 & 29838 & 309.6 \\
& 2012 & 45127 & 468.2 \\
\hline Dominican Republic & 1993 & 12976 & 100.0 \\
& 2008 & 45712 & 352.3 \\
& 2012 & 58951 & 454.3 \\
\hline El Salvador & 1993 & 6938 & 100.0 \\
& 2008 & 21431 & 308.9 \\
& 2012 & 23787 & 342.9 \\
\hline Nicaragua & 1993 & 1756 & 100.0 \\
& 2008 & 8254 & 470.0 \\
& 2012 & 10507 & 598.3 \\
\hline Panama & 1993 & 7253 & 100.0 \\
& 2008 & 23002 & 317.1 \\
& 2012 & 36253 & 499.8 \\
\hline
\end{tabular}

Gulf Cooperation Council (GCC), small states plus United Arab Emirates and Saudi Arabia

\begin{tabular}{|c|c|c|c|}
\hline State & Year & GDP in mil. US\$ & GDP - index \\
\hline Bahrain & 1993 & 5200 & 100.0 \\
& 2008 & 21903 & 421.2 \\
& 2010 & 22945 & 441.2 \\
\hline Kuwait & 1993 & 23941 & 100.0 \\
& 2008 & 147402 & 615.7 \\
& 2011 & 176590 & 737.6 \\
\hline Oman & 1993 & 12493 & 100.0 \\
& 2008 & 60567 & 484.8 \\
& 2011 & 71782 & 574.6 \\
\hline Qatar & 1993 & 7157 & 100.0 \\
& 2008 & 115020 & 1607.1 \\
& 2011 & 172982 & 2417.0 \\
\hline
\end{tabular}

Pacific Islands Forum (small states plus Australia, New Zealand, and Papua New Guinea)

\begin{tabular}{|c|c|c|c|}
\hline State & Year & GDP in mil. US\$ & GDP - index \\
\hline Micronesia, Federated States & 1993 & 198 & 100.0 \\
of, & 2008 & 261 & 131.8 \\
& 2012 & 327 & 165.2 \\
\hline Fiji & 1993 & 1635 & 100.0 \\
& 2008 & 3591 & 219.6 \\
& 2012 & 3882 & 237.4 \\
\hline
\end{tabular}


Journal of Education Culture and Society No. 1_2014

\begin{tabular}{|c|c|c|c|}
\hline Kiribati & 1993 & 49 & 100.0 \\
& 2008 & 131 & 267.3 \\
& 2012 & 176 & 359.2 \\
\hline Marshall Islands & 1993 & 99 & 100.0 \\
& 2008 & 153 & 154.5 \\
& 2012 & 187 & 188.9 \\
\hline Palau & 1993 & 76 & 100.0 \\
& 2008 & 213 & 280.3 \\
& 2012 & 228 & 300.0 \\
\hline Samoa & 1993 & 119 & 100.0 \\
& 2008 & 574 & 482.4 \\
& 2012 & 677 & 568.9 \\
\hline Solomon Islands & 1993 & 411 & 100.0 \\
& 2008 & 646 & 157.2 \\
& 2012 & 1008 & 245.3 \\
\hline Tonga & 1993 & 139 & 100.0 \\
& 2008 & 347 & 249.6 \\
& 2012 & 472 & 339.6 \\
\hline Tuvalu & 1993 & 10 & 100.0 \\
& 2008 & 30 & 300.0 \\
& 2012 & 37 & 370.0 \\
\hline Vanuatu & 1993 & 188 & 100.0 \\
& 2008 & 608 & 323.4 \\
& 2012 & 785 & 417.6 \\
\hline
\end{tabular}

Association of Southeast Asian Nations (ASEAN), small states plus Indonesia, Malaysia, Burma, Philippines, Thailand, Vietnam and Papua-New Guinea

\begin{tabular}{|c|c|c|c|}
\hline State & Year & GDP in mil. US\$ & GDP - index \\
\hline Brunei & 1993 & 4106 & 100.0 \\
& 2008 & 14393 & 350.5 \\
& 2012 & 16954 & 412.9 \\
\hline Cambodia & 1993 & 2534 & 100.0 \\
& 2008 & 10352 & 408.5 \\
& 2012 & 14062 & 554.9 \\
\hline Laos & 1993 & 1328 & 100.0 \\
& 2008 & 5444 & 409.9 \\
& 2012 & 9299 & 700.2 \\
\hline Singapore & 1993 & 59984 & 100.0 \\
& 2008 & 178924 & 298.3 \\
& 2012 & 274701 & 458.0 \\
\hline Timor-Leste & 2000 & 316 & 100.0 \\
& 2008 & 665 & 210.4 \\
& 2012 & 1293 & 409.2 \\
\hline
\end{tabular}

Southern African Development Community (SADC), small states plus Angola, Democratic Republic of the Congo, Mozambique, Republic of South Africa, Tanzania, and Zambia)

\begin{tabular}{|c|c|c|c|}
\hline State & Year & GDP in mil. US\$ & GDP - index \\
\hline Botswana & 1993 & 4160 & 100.0 \\
& 2008 & 11113 & 267.1 \\
& 2012 & 14411 & 346.4 \\
\hline
\end{tabular}




\begin{tabular}{|c|c|c|c|}
\hline Lesotho & 1993 & 722 & 100.0 \\
& 2008 & 1631 & 225.9 \\
& 2012 & 2448 & 339.1 \\
\hline Malawi & 1993 & 2071 & 100.0 \\
& 2008 & 4277 & 206.5 \\
& 2012 & 4264 & 205.9 \\
\hline Mauritius & 1993 & 3263 & 100.0 \\
& 2008 & 9641 & 295.5 \\
& 2012 & 10492 & 321.5 \\
\hline Namibia & 1993 & 2847 & 100.0 \\
& 2008 & 8830 & 310.2 \\
& 2012 & 12807 & 449.8 \\
\hline Seychelles & 1993 & 469 & 100.0 \\
& 2008 & 967 & 206.2 \\
& 2012 & 1032 & 220.0 \\
\hline Swaziland & 1993 & 1357 & 100.0 \\
& 2008 & 3020 & 222.5 \\
& 2012 & 3747 & 276.1 \\
\hline Zimbabwe & 1993 & 6564 & 100.0 \\
& 2008 & 4416 & 164.7 \\
\hline
\end{tabular}

ECOWAS (small states plus Ivory Coast, Ghana, Nigeria)

\begin{tabular}{|c|c|c|c|}
\hline State & Year & GDP in mil. US\$ & GDP - index \\
\hline Benin & $\begin{array}{l}1993 \\
2008 \\
2012\end{array}$ & $\begin{array}{l}2275 \\
6634 \\
7557\end{array}$ & $\begin{array}{l}100.0 \\
291.6 \\
332.2\end{array}$ \\
\hline Burkina Faso & $\begin{array}{l}1993 \\
2008 \\
2012\end{array}$ & $\begin{array}{c}2332 \\
8351 \\
10441\end{array}$ & $\begin{array}{l}100.0 \\
358.1 \\
447.7\end{array}$ \\
\hline Cape Verde & $\begin{array}{l}1993 \\
2008 \\
2012 \\
\end{array}$ & $\begin{array}{c}490 \\
1562 \\
1897 \\
\end{array}$ & $\begin{array}{l}100.0 \\
318.8 \\
387.1\end{array}$ \\
\hline Gambia, The & $\begin{array}{l}1993 \\
2008 \\
2012 \\
\end{array}$ & $\begin{array}{l}755 \\
966 \\
917 \\
\end{array}$ & $\begin{array}{l}100.0 \\
127.9 \\
121.5\end{array}$ \\
\hline Guinea & $\begin{array}{l}1993 \\
2008 \\
2012 \\
\end{array}$ & $\begin{array}{l}3279 \\
3778 \\
6768 \\
\end{array}$ & $\begin{array}{l}100.0 \\
115.2 \\
206.4 \\
\end{array}$ \\
\hline Guinea-Bissau & $\begin{array}{l}1993 \\
2008 \\
2012 \\
\end{array}$ & $\begin{array}{l}237 \\
842 \\
897 \\
\end{array}$ & $\begin{array}{l}100.0 \\
355.3 \\
378.5 \\
\end{array}$ \\
\hline Liberia & $\begin{array}{l}1993 \\
2008 \\
2012 \\
\end{array}$ & $\begin{array}{c}160 \\
850 \\
1767 \\
\end{array}$ & $\begin{array}{c}100.0 \\
531.3 \\
1104.4 \\
\end{array}$ \\
\hline Mali & $\begin{array}{l}1993 \\
2008 \\
2012 \\
\end{array}$ & $\begin{array}{c}2678 \\
8738 \\
10308 \\
\end{array}$ & $\begin{array}{l}100.0 \\
326.3 \\
384.9\end{array}$ \\
\hline
\end{tabular}


Journal of Education Culture and Society No. 1_2014

\begin{tabular}{|c|c|c|c|}
\hline Niger & 1993 & 1607 & 100.0 \\
& 2008 & 5370 & 334.2 \\
& 2012 & 6568 & 408.7 \\
\hline Senegal & 1993 & 5679 & 100.0 \\
& 2008 & 13386 & 235.7 \\
& 2012 & 14160 & 249.3 \\
\hline Sierra Leone & 1993 & 769 & 100.0 \\
& 2008 & 2504 & 325.6 \\
& 2012 & 3796 & 493.6 \\
\hline Togo & 1993 & 1233 & 100.0 \\
& 2008 & 3160 & 256.3 \\
& 2012 & 3814 & 309.3 \\
\hline
\end{tabular}

Common Market for Eastern and Southern Africa (COMESA)

Small states plus Egypt, Democratic Republic of the Congo, Ethiopia, Kenya, Libya, Tanzania, Uganda, and Zambia

\begin{tabular}{|c|c|c|c|}
\hline State & Year & GDP in mil. US \$ & GDP - index \\
\hline Burundi & $\begin{array}{l}1993 \\
2008 \\
2012\end{array}$ & $\begin{array}{c}939 \\
1612 \\
2472\end{array}$ & $\begin{array}{l}100.0 \\
171.7 \\
263.3\end{array}$ \\
\hline Comoros & $\begin{array}{l}1993 \\
2008 \\
2012 \\
\end{array}$ & $\begin{array}{l}264 \\
530 \\
596\end{array}$ & $\begin{array}{l}100.0 \\
200.8 \\
225.8\end{array}$ \\
\hline Djibouti & $\begin{array}{l}1993 \\
2008 \\
2011 \\
\end{array}$ & $\begin{array}{c}466 \\
983 \\
1239\end{array}$ & $\begin{array}{l}100.0 \\
210.9 \\
265.9\end{array}$ \\
\hline Eritrea & $\begin{array}{l}1993 \\
2008 \\
2012 \\
\end{array}$ & $\begin{array}{c}468 \\
1380 \\
3092\end{array}$ & $\begin{array}{l}100.0 \\
294.5 \\
660.7\end{array}$ \\
\hline Madagascar & $\begin{array}{l}1993 \\
2008 \\
2012 \\
\end{array}$ & $\begin{array}{l}3371 \\
9394 \\
9975\end{array}$ & $\begin{array}{l}100.0 \\
278.7 \\
295.9\end{array}$ \\
\hline Malawi & $\begin{array}{l}1993 \\
2008 \\
2012 \\
\end{array}$ & $\begin{array}{ll}2 & 071 \\
4 & 277 \\
4 & 264\end{array}$ & $\begin{array}{l}100.0 \\
206.5 \\
205.9\end{array}$ \\
\hline Mauritius & $\begin{array}{l}1993 \\
2008 \\
2012\end{array}$ & $\begin{array}{c}3263 \\
9641 \\
10492\end{array}$ & $\begin{array}{l}100.0 \\
295.5 \\
321.5\end{array}$ \\
\hline Rwanda & $\begin{array}{l}1993 \\
2008 \\
2012\end{array}$ & $\begin{array}{l}1972 \\
4712 \\
7103\end{array}$ & $\begin{array}{l}100.0 \\
238.9 \\
360.2\end{array}$ \\
\hline Seychelles & $\begin{array}{l}1993 \\
2008 \\
2012 \\
\end{array}$ & $\begin{array}{c}469 \\
967 \\
1032 \\
\end{array}$ & $\begin{array}{l}100.0 \\
206.2 \\
220.0\end{array}$ \\
\hline Swaziland & $\begin{array}{l}1993 \\
2008 \\
2012\end{array}$ & $\begin{array}{l}1357 \\
3020 \\
3747\end{array}$ & $\begin{array}{l}100.0 \\
222.5 \\
276.1\end{array}$ \\
\hline
\end{tabular}




\begin{tabular}{|c|c|c|c|}
\hline Zimbabwe & 1993 & 6564 & 100.0 \\
& 2008 & 4415 & 67 \\
& 2012 & 10814 & 164.7 \\
\hline
\end{tabular}

Economic Community of Central African States (ECCAS), small states plus Angola, Democratic Republic of the Congo, Cameroon

\begin{tabular}{|c|c|c|c|}
\hline State & Year & GDP in mil. US \$ & GDP - index \\
\hline Burundi & 1993 & 939 & 100.0 \\
& 2008 & 1612 & 171.7 \\
& 2012 & 2472 & 263.3 \\
\hline Central African Republic & 1993 & 1299 & 100.0 \\
& 2008 & 1983 & 152.7 \\
& 2012 & 2139 & 164.7 \\
\hline Chad & 1993 & 1463 & 100.0 \\
& 2008 & 8361 & 571.5 \\
& 2012 & 11018 & 753.1 \\
\hline Congo, Republic of the & 1993 & 1919 & 100.0 \\
& 2008 & 11675 & 608.4 \\
& 2012 & 17870 & 931.2 \\
\hline Equatorial Guinea & 1993 & 152 & 100.0 \\
& 2008 & 15471 & 10178.3 \\
& 2012 & 17697 & 1042.8 \\
\hline Gabon & 1993 & 4379 & 359.3 \\
& 2008 & 15732 & 426.1 \\
\hline Sao Tome and Principe & 2012 & 18661 & 100.0 \\
& 2000 & 77 & 237.7 \\
& 2008 & 183 & 342.9 \\
\hline
\end{tabular}

Source: The Authors. The World Bank Databank: GDP (current US\$). Retrieved from https://www. data.worldbank.org/indicator/NY.GDP.MKTP.CD; The World Factbook. Country Comparison: GDP (Purchasing Power Parity) https://www.cia.gov/library/publications/the-world-factbook/rankorder/2001rank.html;

According to the Table 3 in small states of the European Union it is evident that only one economy of small states can meet the criteria for a small economy (Malta), reflecting the high level of development in the EU compared to the rest of the world. Small states that joined the EU in 2004 and 2013 have recorded a much higher GDP growth in the past twenty years than small states that are in the EU since its establishment (the Benelux countries), or since 1973 (Denmark), because they are smaller economies on the whole and because they represent transitional economies, whose base GDP was very low in the first year researched (1993). Due to most EU countries entering the recession in 2009, the economic growth of small EU member states, the former transitional economies, slowed down after the recorded growth in the early 1990s. Croatia, which became an EU member in 2013, also recorded a decline in GDP from 1999-2000, and has been through a recession thrice since independence (1999-2000, 2009-2010 and 2012). Malta, as the only small economy and Cyprus, as one of the smallest economies in the EU, recorded a level of growth whose size fell between small old EU member states 
and small new EU member states which have undergone transition in the analyzed period. The record-holder among small EU countries by GDP growth in the last twenty years is Latvia (its GDP index rose from 100 to 635).

Small states in Europe that are not members of the EU and not undergoing the transition process are mainly small economies, with Switzerland as the only exception. All these economies are highly developed (Table 3). The recession that emerged in 2009 affected them less than most EU member states in general, with the exception of Iceland.

Small transitional countries of the Western Balkans have recorded a GDP growth by approximately 3.8 (Macedonia) and 13.5 times (Bosnia and Herzegovina) from 1993 to 2012. In Albania, and even more so in Bosnia and Herzegovina, a very large increase in GDP reflects a very low base in year 1993 (Table 3). Small countries of the Western Balkans are among the European countries that are least developed.

Small member states of the Commonwealth of Independent States (CIS) also recorded a GDP growth by three (Moldova) to as much as eight times (Armenia) in the observed period (Table 3), which is primarily a reflection of the very low initial GDP level in 1993. These are also the small economies and states that are the least developed members of the CIS.

All CARICOM member states are small states, and, aside from Trinidad and Tobago, small economies. CARICOM has existed for 40 years, and most member states joined the organization during its establishment or a year after its founding. Small island economies of the Caribbean (also members of the Commonwealth) recorded a growth of GDP by approximately two to four times in the observed period, with the exception of Haiti (not a member of the Commonwealth, only became a CARICOM member state in 2002). Suriname is the record holder for the increase in GDP among the members of CARICOM, and Guyana holds second place, meaning these small economies recorded a much higher GDP growth than the small island economies of the Caribbean. Trinidad and Tobago, which is not a small economy, takes the position between Guyana and small economies of the Caribbean islands by the increase of its GDP (Table 3).

In the Gulf Cooperation Council (GCC), four small member states are not small economies, which are completely absent from GCC, reflecting a higher GDP, the effect of oil and gas wealth, which are exported from the Persian Gulf states. Small states, members of the GCC, have recorded a high growth of GDP in the analyzed period, while Qatar is the absolute record-holder, its GDP growing by 24 times (Table 3). The GDP of these countries depends primarily on their wealth in oil and gas and the price of these fuels on the world market. Decline in energy prices due to oil and gas importers entering recession in year 2009, reflected negatively on the GDPs of these countries, but the rapid increase in prices also increased their GDPs, which have a tendency of growth.

The Pacific Islands Forum is made up of a total of 13 countries, 10 of which are small countries, and also small economies. The insular and archipelagic countries of the Pacific are small by their surface area, their population and size of their economy. The differences in GDP growth among these small economies 
have been significant in the last 20 years. The GDP of the Federated States of Micronesia has increased by just 1.6 times and for the Marshall Islands by less than two times. At the same time, the GDP of Vanuatu has increased by more than four times, and the GDP of Samoa by as much as 5.7 times (Table 3), which is also an indicator of different development potentials, which are decreased on small, low islands of Micronesia, as opposed to the larger and higher islands of Polynesia and Melanesia.

There are five small states, three of which are also small economies (Cambodia, Laos, Timor-Leste), and two are not (Brunei, Singapore) in the Association of Southeast Asian Nations (ASEAN). There is a remarkable difference in development, as measured by GDP per capita between the two groups of small states. What they all have in common, however, is the high level of GDP growth during the observed period, regardless of the size of their economy and the initial level of GDP, because the GDP of developed and major economies (Brunei, Singapore) increased by more than four times, while at the same time the GDP of Laos grew seven times and 5.5 times in Cambodia (Table 3).

The group of analyzed African countries is made up of small states, most of which are also small economies, given the very low GDP per capita. A significant part of the analyzed countries of Africa were considered small precisely due to the small size of their economy and so the group of small states includes 15 African states, which size and population do not meet the set criteria, but they are small economies according to the criterion of the total GDP. Small African states were analyzed according to membership in several regional economic organizations, with membership of some small states repeated in several regional economic organizations. There should be mention of an important moment in regional economic organizations of Africa, which is less influential or has an almost irrelevant role in small member states of regional economic organizations on other continents, and it is at least a basic level of political stability and political authority that is democratically legitimized and working on the development of the economy (which in many parts of Africa today is not the case nor was it in the last two decades). Military coups and civil wars were a frequent occurrence in Africa, particularly in Western and Equatorial Africa. Therefore, the GDP growth in these countries cannot be high, although most of them recorded an increase of the population, which is much larger than that in other parts of the world, in the same period. A high, even incredible increase in GDP during the observed period, which is a characteristic of some countries in Africa (e.g. Equatorial Guinea as an absolute record-breaker among all the researched countries, then Chad, the Republic of Congo and Gabon to a lesser extent, see Table 3) due to the beginning of oil exploitation, and preceded by a very low GDP of these economies, which increased manifold based on oil exports. The mentioned countries are now exactly where the Gulf States were a few decades ago in this characteristic, when stronger exploitation and a large increase in prices led to an "explosion" of GDP of these countries. 


\section{CONCLUSION}

Data on GDP growth of small states within integrations and out of them (Table 3), point out the limitations of quantitative criteria that despite their exactness do not provide complete answers without delving into the context, which just confirms the notion that during the research of small states it is necessary to realize their specific position in the region they are located in, as well as the circumstances in the international community that significantly influence their policies.

Similarities between small economies and small states, who are members of regional economic organizations and integration, exist along with differences that arise in relation to member countries from other regional economic organizations / integrations. However, there are also large differences in GDP trajectories between small member states of the same regional economic organization/integration.

The study did not find enough evidence to be able to determine that the size of the national economy of small states is a factor that directly affects the movement of GDP, according to the principle that smaller economies have a faster GDP growth in the same period, which is the answer to the first hypothesis in this paper. Changes in the GDP of small states in the studied period is primarily dependent on factors such as: (1) whether the economy is in transition or not (post-communist countries had different conditions for development from advanced capitalist economies of Europe), which is coupled with the height of the base taken as the starting year of the studies period (1993, the period after the start of transition); (2) political (in)stability, the presence or absence of wars and conflicts (especially important in Africa); (3) energy prices at the world market and the stage of development of the domestic energy industry - the most important factor when it comes to GCC member states and states highly dependent on oil exports in general, in Africa and Asia; (4) envelopment by the recession and the successfulness of the fight against it since 2009 until today.

If we accept these factors as fundamental determinants of trends in GDP growth of small countries in the last two decades, the answer to the second hypothesis set at the beginning of this paper is that there is sufficient evidence, found by tracking the movement of the GDP of small states, about the regional differences between the factors, as well as the complexity of internal and external circumstances that affect the growth of GDP of small states. These factors are much more complex than simply the size of the economies of small states.

\section{REFERENCES}

Aiyar, S.S.A. (2008). Small States: Not Handicapped and Under-Aided, but Advantaged and OverAided. CATO Journal, 28(3), 449-478.

Alesina, A., \& Spolaore, E. (2003). The Size of Nations. Cambridge: MIT Press

Armstrong, H.W., \& Read, R.A. (1998). Trade and Growth in Small States: The Impact of Global Trade Liberalisation. Working Papers, ec 5/98. Departments of Economics: Lancaster University.

Armstrong, H.W., \& Read, R. A. (2000). Comparing the Economic Performance of Dependent Territories and Sovereign Microstates. Economic Developement and Cultural Change, 48, 285-306.

Armstrong, H.W., \& Read, R.A. (2004). The Economic Performance of Small States and Islands: The Importance of Geography. Islands of the World III International Conference: Changing Islands - Changing Worlds. Kinmen Island: Taiwan. 
Briguglio, L., Persaud, B., \& Stern, R. (2005). Towards an Outward - Oriented Developement Stategy for Small States: Issues, Opportunities and Resilince - Building. Washington: The World Bank.

Briguglio, L. (2011). Economic Vulnerability and Resilience with Reference to Small States. ECLAC Conference September 2011.

Easterly, W., \& Kraay, A. (2000). Small States, Small Problems? Income, Growth and Volatility in Small States. World Developement, 28(11), 2013-2027.

Handel, M. (1981). Weak States in the International System. New York: Frank Cass \&Co.Ltd

Hanggi, H., \& Regnier, P. (2000). The Small State and the Triad: the Case of Switzerland's Foreign Policy Towards East Asia, Study in NRF Policy, National Foreign Policy Program.

Hey, J. (Ed.). (2003). Small States in World Politics: Explaining Foreign Policy Behaviour. Boulder: Lynne Rienner Publishers.

Kautto, M. (Ed.). (2001). Nordic Welfare States in the European Context. London: Routledge.

Krugman, P. (1998). The Role of Geography in Developement. Paper prepared for the Annual World Bank Conference on Developement Economics. Washington, D.C.

Kurečić, P. (2012). Problematika defiQIDOMP DOK Gढ़DDD $>7$ KHSLREOP VRI Glfining small states]. Hroatski geografski glasnik, 74 (2), 89-112.

Luthria, M., \& Dhat, S. (2005). Pacific 2020, Background Paper: Framework for Growth. Commonwealth of Australia.

Parsad, N. (2013). Small but Smart: Small States in the Global System. In: Cooper, A.F., \& Shaw, T., (Eds.). (2009). The Diplomacies of Small States - Between Vulnerability and Resilience. London: Palgrave Macmillan.

Ramkissoon, R. (2002). Explaining Differences in Economic Performance in Carribbean Economies. Presented at International Conferece on Island and the World Economy: small Island economies in the Era of Globalization. Center for International development: Harvard University.

Rapaport, J., Muteba, E., \& Therattil, J. J. (1971). Small States \& Territories, Status and Problems, United NationsInstitute for Training and Research Study, New York.: Arno Press.

Schiff, M. (1997). Small is beautiful: Preferential Trade Agreements and the Impact of Country Size, Market Share, Trade Policy and Smuggling. Journal of Economic Integration, 12(3), 359-87.

Schiff, M. (2002). Regional Integration and Developement in Small States. Policy Research Working Paper 2797. Washington: The World Bank Developement Research Group.

Thorhallsson, B. (1996). The Size of States in the European Union: Theoretical and Conceptual Perspectives. European Integration. 28(1), 7-31

The World Bank Databank: GDP (current US\$). Retrieved from https://www.data.worldbank.org/indicator/NY.GDP.MKTP.CD

The World Factbook. Country Comparison: GDP (Purchasing Power Parity) https:/ / www.cia.gov/library/ publications/the-world-factbook/rankorder/2001rank.html

The World Factbook. Country Comparison: Population, Retrieved from https://www.cia.gov/library/ publications/the-world-factbook/rankorder/2119rank.html

Winters. L.A., \& Martinis, P.M.G. (2004). When Comparative Advantage is Not Enough: Buisiness Costs in Small Remote Economies. World Trade Rewiev, 3(3), 347-383. 